\title{
Pengaruh Faktor-Faktor Kompetensi Terhadap Kinerja Tenaga Perpustakaan
}

\author{
Cahyo Trianggoro, Pawit M. Yusup, Wina Erwina \\ Law Firm Widyawan \& Partners Librarian \\ Departemen Ilmu Informasi dan Perpustakaan Fikom Unpad \\ The Energy, 9th Floor, J1. Jenderal Sudirman Kav. 52-53 Jakarta 12190 \\ J1.Raya Bandung-Sumedang Km.21 Sumedang 45363 \\ Email: ctriangs@yahoo.com
}

\begin{abstract}
ABSTRAK - Penelitian ini menguji pengaruh faktorfaktor kompetensi terhadap kinerja tenaga perpustakaan pada UPT Perpustakaan CISRAL Universitas Padjadjaran. Tujuan dari penelitian ini untuk mengetahui seberapa besar kontribusi yang diberikan oleh faktor-faktor kompetensi yang terdiri atas Pengetahuan (Knowledge), Keterampilan (Skills), dan Sikap (Attitude) terhadap kinerja tenaga perpustakaan. Teknik dalam pengumpulan data menggunakan angket, observasi, wawancara dan studi pustaka. Responden dalam penelitian ini adalah para tenaga Perpustakaan pada UPT Perpustakaan CISRAL Universitas Padjadjaran. Hasil dari penelitian ini menunjukan bahwa faktor-faktor kompetensi memberikan pengaruh yang signifikan terhadap kinerja tenaga perpustakaan.
\end{abstract}

Kata kunci: Kompetensi, Tenaga Perpustakaan, CISRAL

ABSTRACT - This study examined the influence of competence factors to the performance of library staff in the library of the Padjadjaran University UPT CISRAL. The aimed of this research was to know how large the contribution given by the competency factors of Knowledge, Skills, and Attitude towards library staff performance. Using data collection techniques in questionaires form, obeservations, interviews and literature studies. The respondents in this study was the library staff of the CISRAL University of Padjadjaran. The results of this research showed the factors significantly influence the competence of library staff performance.

Key words: Competence, Library Staff, CISRAL

\section{PENDAHULUAN}

Universitas Padjadjaran merupakan salah satu perguruan tinggi yang ada di Indonesia yang memiliki visi "Menjadi Universitas Unggul Dalam
Penyelenggaraan Pendidikan Kelas Dunia" (Unpad, 2012). Sarana dan prasarana terutama yang mendukung kegiatan akademik dengan kualifikasi yang mampu memenuhi Standar Internasional merupakan hal mutlak yang harus dipenuhi oleh Universitas Padjadjaran untuk merealisasi visi tersebut. Sarana dan prasarana yang dimaksud adalah perpustakaan yang memenuhi standar internasional, ditinjau baik dari segi fisik bangunan maupun sumber daya manusia (human resources) yang mengelola perpustakaan tersebut.

Untuk dapat mendukung visinya, Universitas Padjadjaran membentuk suatu Unit Pelaksana Teknis perpustakaan yang diberi nama CISRAL (Center of Information Scientific Resources and Library) yang terletak di Jalan Dipati Ukur No. 46, Bandung. UPT Perpustakaan UNPAD dalam hal ini CISRAL didalam menjalankan fungsinya sebagai sarana belajar mengajar, penelitian dan pengabdian pada masyarakat sebagai wujud nyata Tri Dharma Perguruan Tinggi, senantiasa memberikan pelayanan yang baik kepada sivitas akademika khususnya dan masyarakat umum sebagai pengguna pada umumnya. CISRAL sebagai salah satu sumber belajar yang dimiliki oleh Universitas Padjadjaran tentunya memiliki tujuan untuk mampu memenuhi kebutuhan para sivitas akademik Universitas Padjadjaran.

Dalam sebuah perguruan tinggi, keberadaan perpustakaan memiliki peran sentral yang sangat penting bagi suatu perguruan tinggi. Perpustakaan merupakan sarana pendukung yang vital dalam menunjang kegiatan dari sivitas akademiknya yang terdiri dari dosen dan mahasiswa. Kegiatan dari sebuah perguruan tinggi yang dilakukan oleh sivitas akademik termaktub dalam tri dharma perguruan tinggi yaitu: Pendidikan, Penelitian, dan Pengabdian Kepada Masyarakat. Dari ketiga 
kegiatan tersebut, seluruhnya bergantung kepada perpustakaan dalam rangka menyediakan sumbersumber bahan belajar dan mengajar serta penyediaan bahan-bahan dalam rangka mendukung kegiatan penelitian (research) bagi para sivitas akademik perguruan tinggi. Perguruan tinggi pun memiliki tanggung jawab dalam menyediakan bahan bacaan sebagai bentuk pengabdian kepada masyarakat. Dari seluruh kegiatan yang sudah digambarkan tadi, kita dapat merasakan bahwa perpustakaan pada perguruan tinggi memiliki peran yang strategis dalam mendukung kegiatan perguruan tinggi.

Peran yang begitu besar dari suatu perpustakaan tidak akan terwujud tanpa didukung oleh sumber daya manusia yang memiliki kompetensi, baik kompetensi personal maupun kompetensi profesional. Spencer dalam Moeheriono mendefinisikan kompetensi sebagai karakteristik yang mendasari seseorang berkaitan dengan efektifitas kinerja individu dalam pekerjaanya atau karakteristik individu yang memiliki hubungan kausal atau sebagai sebab akibat dengan kriteria yang dijadikan acuan, efektif atau berkinerja prima atau superior di tempat kerja pada situasi tertentu (A competency is an underlying characteristic of an individual that is causally related to criterian referenced effective and or superior performance in a job or a situation) (Moeheriono 2009, 9). Spencer berpendapat bahwa kompetensi terdapat di dalam setiap diri manusia dan selamanya ada pada kepribadian seseorang yang dapat memprediksikan tingkah laku dan performansi secara luas pada semua situasi dan tugas pekerjaan atau job tasks. Secara mendasar, kompetensi pada seseorang terdiri atas 3 unsur yakni Pengetahuan (Knowledge), Keterampilan (Skill), dan Sikap (Attitude) atau disebut KSA.

Tidak dapat dipungkiri bahwa kompetensi memegang peranan penting bagi seorang profesional yang bekerja di perpustakaan. Dengan kompetensi dan profesionalisme yang dimilikinya, tenaga perpustakaan akan memiliki kinerja sesuai dengan kompetensi yang dimilikinya, sehingga pelayanan yang diberikan oleh perpustakaan dapat berjalan secara optimal. Sulistyo basuki, dalam bukunya Pengantar Ilmu Perpustakaan mengatakan bahwa "profesi memiliki arti kata pekerjaan atau sebuah sebutan pekerjaan, terutama pekerjaan yang memerlukan pendidikan atau latihan" (Sulistyo Basuki 1991, 147).
Spencer dalam Moeheriono, menyatakan bahwa "Hubungan antara kompetensi dan kinerja sangat erat sekali, karena kompetensi dan kinerja memiliki hubungan sebab akibat (causally related) di antara keduanya". Moeheriono mendefinisikan kinerja sebagai gambaran mengenai tingkat pencapaian pelaksanaan suatu program kegiatan atau kebijakan dalam mewujudkan sasaran, tujuan, visi, dan misi organisasi yang dituangkan melalui perencanaan strategis suatu organsisasi (Moeheriono 2009, 9). CISRAL sebagai UPT yang mendukung langkah institusi induknya yakni Universitas Padjadjaran tentunya perlu memiliki sumber daya manusia, dalam hal ini tenaga perpustakaan yang memiliki kompetensi di bidang pengelolaan dan pelayanan perpustakaan sehingga tenaga perpustakaan tersebut mampu memiliki kinerja yang baik dalam melakukan pengelolaan dan pelayanan perpustakaan sehingga dapat menjalankan fungsinya secara optimal. Dengan kinerja terbaik, perpustakaan CISRAL kelak mampu menjadi World Class Library karena sumber daya manusia yang dimilikinya telah memiliki kompetensi dengan standar yang sesuai dengan standar internasional.

Studi yang mendalam berupa penelitianpenelitian yang mengkaji bidang sumber daya manusia di perpustakaan masih jarang ditemukan. Oleh karena itu penulis tertarik untuk meneliti tentang kompetensi sumber daya manusia yang dimiliki oleh perpustakaan CISRAL. Dalam konteks penelitian ini, sumber daya manusia yang dimaksud adalah tenaga perpustakaan pada perpustakaan CISRAL yang melakukan fungsi pelayanan langsung (direct reader services) maupun fungsi pelayanan tidak langsung (indirect reader services) terhadap pengguna perpustakaan. Diperlukan suatu studi lanjutan untuk mengetahui seberapa besar pengaruh antara kompetensi terhadap kinerja tenaga perpustakaan yang terdapat di CISRAL, sehingga nantinya diharapkan mampu memberikan masukan kepada CISRAL dalam mengembangkan sumber daya manusia dalam rangka menuju "CISRAL World Class Library".

\section{METODE}

Penelitian ini menggunakan metode penelitian kuantitatif korelasional. Metode korelasional merupakan kelanjutan dari metode kuantitatif 
deskriptif dimana data yang telah dihimpun kemudian dianalisis apakah memiliki hubungan antara variabel yang satu dengan variabel yang lain. Penelitian korelasional digunakan untuk meneliti hubungan antara dua variabel atau lebih. Tujuannya adalah untuk meneliti sejauh mana variabel pada satu faktor berkaitan dengan variabel pada faktor lain (Kountur 2007, 111).

Data hasil penelitian di lapangan akan dianalisis menggunakan analisis statistik inferensial. Metode statistik inferensial adalah semata - mata teknik atau alat yang dipakai dalam membuktikan kebenaran teori probabilitas yang umumnya digunakan dalam penelitian ilmu sosial yang berkaitan dengan masalah perbedaan, masalah hubungan, dan masalah - masalah korelasional (Bungin 2010, 182).

\section{PEMBAHASAN HASIL PENELITIAN}

Setelah melakukan pengambilan data di lapangan dengan menyebarkan kuesioner, data kemudian diolah menggunakan teknik analisis jalur (path analysis). Teknik analisis jalur (path analysis) dipilih untuk menguji masing-masing faktor kompetensi secara parsial. Setiap faktor kompetensi diuji pengaruhnya terhadap kinerja tenaga perpustakaan baik pengaruh secara langsung maupun pengaruh tidak langsung melalui faktor kompetensi yang lainnya. Berikut penulis sajikan rangkuman hasil analisis jalur dalam tabel di bawah ini:
Tabel 4.1

Rangkuman Besaran Pengaruh X1, X2 dan X3 terhadap Y

\begin{tabular}{|c|c|c|c|c|c|}
\hline \multirow{3}{*}{$\begin{array}{c}\text { Variabel } \\
\text { Independen }\end{array}$} & \multicolumn{5}{|c|}{$\begin{array}{l}\text { Pengaruh variabel independen X1, X2 } \\
\text { dan X3 terhadap variabel dependen } Y\end{array}$} \\
\hline & \multirow[t]{2}{*}{$\begin{array}{l}\text { Pengaruh } \\
\text { Langsung }\end{array}$} & \multicolumn{3}{|c|}{$\begin{array}{c}\text { Pengaruh Tidak } \\
\text { Langsung } \\
\text { (pengaruh } \\
\text { melalui) }\end{array}$} & \multirow[t]{2}{*}{ Total } \\
\hline & & $\mathbf{X}_{1}$ & $\mathbf{X}_{2}$ & $\mathbf{X}_{\mathbf{3}}$ & \\
\hline $\mathrm{X} 1$ & $0,15 \%$ & & $\begin{array}{l}1,3 \\
1 \%\end{array}$ & $\begin{array}{l}0,2 \\
1 \%\end{array}$ & $1,67 \%$ \\
\hline $\mathrm{X} 2$ & $35,66 \%$ & $\begin{array}{c}1,31 \\
\%\end{array}$ & & $\begin{array}{l}6,4 \\
6 \%\end{array}$ & $43,43 \%$ \\
\hline $\mathrm{X} 3$ & $2,44 \%$ & $\begin{array}{c}0,21 \\
\%\end{array}$ & $\begin{array}{l}6,4 \\
6 \%\end{array}$ & & $9,11 \%$ \\
\hline \multicolumn{5}{|c|}{$\begin{array}{l}\text { Pengaruh secara simultan } \mathrm{X} 1, \mathrm{X} 2 \text { dan } \mathrm{X} 3 \\
\text { terhadap } \mathrm{Y}\end{array}$} & $54,21 \%$ \\
\hline \multicolumn{5}{|c|}{$\begin{array}{l}\text { Pengaruh Akibat Faktor Lainnya Yang Tidak } \\
\text { Diteliti }\end{array}$} & $45,79 \%$ \\
\hline
\end{tabular}

Sumber: penelitian 2012

Dari tabel diatas dapat diketahui secara simultan bahwa ketiga variabel bebas yakni variabel knowledge, skills dan attitude berpengaruh signifikan terhadap kinerja pustakawan, sedangkan hasil pengujian secara parsial hanya variabel skills saja yang berpengaruh signifikan terhadap kinerja Tenaga Perpustakaan. Pengujian yang dilakukan pada penelitian ini bertujuan untuk mengukur sejauh mana kesadaran tenaga perpustakaan pada perpustakaan CISRAL akan pengaruh faktor-faktor kompetensi terhadap kinerja tenaga perpustakaan. Hasil dari penelitian ini menunjukan bahwa tenaga perpustakaan pada perpustakaan CISRAL menyadari bahwa faktorfaktor kompetensi memiliki pengaruh terhadap kinerja mereka. Pengaruh tersebut menunjukan hubungan kausal dimana semakin tinggi kompetensi yang dimiliki oleh pustakawan, maka akan semakin baik pula kinerja yang dapat dihasilkan oleh tenaga perpustakaan. Secara parsial, diketahui bahwa tenaga perpustakaan sangat menyadari bahwa faktor keterampilan (skill) sangat mempengaruhi kinerja mereka. Sedangkan faktor lain seperti pengetahuan (knowledge), dan sikap (attitude) belum memberikan kontribusi terhadap kinerja. Dari data yang terdapat diatas, Penulis melihat bahwa faktor-faktor yang belum memberikan kontribusi terhadap kinerja perlu 
Trianggoro, dkk.

mendapat perhatian ekstra. Faktor-faktor tersebut sangat penting karena perpustakaan sebagai organisasi yang berorientasi pada layanan terhadap pengguna tidak hanya dapat dilayani oleh sumber daya manusia yang hanya memiliki keterampilan yang baik, namun juga pengetahuan yang luas serta pelayanan yang ramah serta dari sumber daya manusia yang mengelola perpustakaan CISRAL. Tanpa didukung pengetahuan yang luas serta pelayanan yang ramah terhadap pengguna, sumber daya yang terdapat pada perpustakaan CISRAL tidak dapat secara optimal didaya gunakan oleh para pengguna perpustakaan. Diperlukan suatu program pengembangan untuk meningkatkan kompetensi baik melalui pendidikan lanjutan secara formal maupun pelatihan-pelatihan kepada tenaga perpustakaan CISRAL. Dengan program pengembangan tersebut, diharapkan kompetensi yang dimiliki oleh tenaga perpustakaan akan semakin baik sehingga realisasi untuk WORLD CLASS UNIVERSITY dapat terwujud.

\section{SIMPULAN DAN SARAN.}

\section{Simpulan}

Kompetensi tenaga perpustakaan merupakan faktor penting yang mempengaruhi kinerja tenaga perpustakaan. Kompetensi tenaga perpustakaan terdiri atas tiga faktor yakni Pengetahuan (Knowledge), Keterampilan (Skill), dan Sikap (Attitude). Secara simultan, kompetensi memiliki pengaruh yang signifikan terhadap kinerja tenaga perpustakaan. Pengaruh tersebut menunjukan bahwa semakin baik kompetensi yang dimiliki oleh tenaga perpustakaan akan memberikan pengaruh yang semakin baik pula terhadap kinerja tenaga perpustakaan. Dari ketiga faktor kompetensi tenaga perpustakaan, faktor Keterampilan (Skill) memberikan kontribusi pengaruh yang paling besar terhadap kinerja tenaga perpustakaan.

\section{Saran}

Melihat begitu besarnya pengaruh kontribusi faktor-faktor kompetensi terhadap kinerja tenaga perpustakaan, diperlukan suatu program untuk pengembangan kompetensi tenaga perpustakaan berupa pelatihan-pelatihan yang mampu meningkatkan Pengetahuan (Knowledge), Keterampilan (Skill), dan Sikap (Attitude).

\section{DAFTAR PUSTAKA}

Kismiyati, Titiek. "Kesiapan Sertifikasi Pustakawan". Makalah disampaikan pada Seminar Nasional Perpustakaan dengan tema Kompetensi dan Sertifikasi Pustakawan dalam Menghadapi Tantangan dan Persaingan Global 14 September 2011, IPB-ICC Bogor.

Kountur, Ronny. 2007. Metode Penelitian: Untuk Penulisan Skripsi dan Tesis. Jakarta: Penerbit PPM.

Moeheriono. 2009. Pengukuran Kinerja Berbasis Kompetensi. Bogor: Ghalia Indonesia,

Sulistyo Basuki. 1991. Pengantar Ilmu Perpustakaan. Jakarta: Gramedia Pustaka Utama.

Unpad. 2012. Visi, Misi, dan Tujuan Unpad.

Diakses dari http://www.unpad.ac.id/ universitas/visi-misi-tujuan/ 